Article

\title{
Employment, Disabled People and Robots: What Is the Narrative in the Academic Literature and Canadian Newspapers?
}

\author{
Gregor Wolbring \\ Department of Community Health Sciences, University of Calgary, Calgary, AB T2N4N1, Canada; \\ gwolbrin@ucalgary.ca; Tel.: +1-403-210-7083
}

Academic Editors: António B. Moniz and Bettina-Johanna Krings

Received: 27 February 2016; Accepted: 25 April 2016; Published: 28 April 2016

\begin{abstract}
The impact of robots on employment is discussed extensively, for example, within the academic literature and the public domain. Disabled people are known to have problems obtaining employment. The purpose of this study was to analyze how robots were engaged with in relation to the employment situation of disabled people within the academic literature present in the academic databases EBSCO All—an umbrella database that consists of over 70 other databases, Scopus, Science Direct and Web of Science and within $n=300$ Canadian newspapers present in the Canadian Newsstand Complete ProQuest database. The study focuses in particular on whether the literature covered engaged with the themes of robots impacting (a) disabled people obtaining employment; (b) disabled people losing employment; (c) robots helping so called abled bodied people in their job to help disabled people; or (d) robots as coworkers of disabled people. The study found that robots were rarely mentioned in relation to the employment situation of disabled people. If they were mentioned the focus was on robots enhancing the employability of disabled people or helping so called abled-bodied people working with disabled clients. Not one article could be found that thematized the potential negative impact of robots on the employability situation of disabled people or the relationship of disabled people and robots as co-workers. The finding of the study is problematic given the already negative employability situation disabled people face.
\end{abstract}

Keywords: robot; industrial robot; service robot; social robot; employment; job; work; occupation; newspapers; academic literature

\section{Introduction}

The impact of robots on employment is discussed extensively within the academic literature (see, for example, [1-14]) and in the public domain (for example, [15,16]) addressing the following main themes: (a) people keeping their job; (b) people obtaining new jobs; and (c) people interacting with robots as co-workers. Two studies—one from the USA [17] and one from Europe [18]—explored this question of the impact of robots on employment. The US study [17] surveyed 1896 experts of technology and Internet analyses on the impact of robotic advancements and artificial intelligence. This study found that $48 \%$ of the experts envisioned robots and digital agents displacing a significant number of blue- and white-collar workers with the potential to increase "income inequality, masses of people who are effectively unemployable, and breakdowns in the social order", compared to $52 \%$ of the experts who voiced the opinion that robots or digital agents will not lead to a decrease in available jobs but rather will create new types of jobs by 2025 [17]. The study also highlighted the views that existing social institutions including the educational system "are not up to the challenge of preparing workers for the technology- and robotics-centric nature of employment in the future" [17]. The EU study [18] concluded that: "EU citizens have well-defined specific attitudes about robots: on the one hand they 
express the utilitarian view that robots are useful and good because they do jobs that are either too hard or too dangerous for, or helpful to, people; on the other hand, they express a degree of caution, in that robots steal people's jobs and require careful management" [18]. According to the EU study 39\% agree and $51 \%$ disagree that "widespread use of robots can boost job opportunities in the EU" (10\% have no opinion) [18] whereby vulnerable parts of the population have a more negative sentiment.

Disabled people are one vulnerable group which has a hard time finding employment. In 2014, the US labor force participation rate among non-institutionalized civilians ages 16 to 64 , found that $16.2 \%$ of the population experienced a work limitation (disabled people) and $77.5 \%$ of people did not experience a work limitation (non-disabled people) [19]. Other OECD countries show similar numbers [19]. The employment numbers in the USA "for persons with a disability declined by 0.5 percentage point from 2013 to 2014, while the ratio for those with no disability increased by 0.6 percentage point" [20]. Employment rates vary by type of so called impairment. Employment rates are highest for people labeled as hearing impaired (50.2\%) and vision impaired (39.6\%) and lowest for people with self-care (15.2\%) and independent living (15.3\%) limitations [21]. According to the United Nations Enable webpage: $80 \%$ to $90 \%$ of persons with disabilities of working age are unemployed in developing countries, whereas in industrialized countries the figure is between $50 \%$ and $70 \%$ [22].

A news item from Canadian Broadcasting Corporation (CBC) reported the following numbers of employment of disabled people: Mild disability—68\% employment rate; Moderate disability-54\%; Severe disability-42\%; Very severe-26\% [23] (see also [24]). "More than half of all workers with a disability were concentrated in four general occupation groups: service workers (except protective services) with $18.2 \%$, followed by administrative support (15.1\%), sales workers (10.4\%) and management, business and finance (8.9\%). Among specific occupations, janitors and building cleaners had the highest number of employees with a disability at 315,000 , or $11.8 \%$ of all workers in that field, followed by drivers/sales workers and truck drivers with 263,000 people, cashiers with 256,000 and retail salespeople with 223,000. Of the occupations with 100,000 or more people employed, dishwashers had the highest rate of employees with disabilities at $14.3 \%$, followed by refuse and recyclable material collectors $(12.7 \%)$, personal care aides $(11.9 \%)$, and janitors and building cleaners $(11.8 \%)^{\prime \prime}$ [25] (for data tables see [26-28]).

Given the problems disabled people face in obtaining employment and given that the impact of robots on employment is discussed extensively within the academic literature and in the public domain especially around robots taking over the jobs of people and generating new job opportunities for people, and given that many of the jobs predicted to be taken over by robots are often the ones most accessible to disabled people, the presented study provides descriptive qualitative and quantitative data from the international academic literature and Canadian newspaper articles on the discourse around robots and their impact on the employment situation of disabled people.

This study investigates the following research question: How are disabled people mentioned in academic and newspaper discourses around robots and employment/jobs/work? In more detail, the study looked at whether the literature looked at robots impacting (a) disabled people obtaining employment; (b) disabled people losing employment; (c) robots helping so called abled bodied people in their job to help disabled people; or (d) robots as coworkers of disabled people.

\section{Experimental Section}

The analytical framework of this paper is a framing analysis, which is typically used to investigate differing interpretations of a topic or an issue [29]. According to Entman, the basis of framing is to "select some aspects of perceived reality, and make them more salient in a communicating text, in such a way as to promote a particular problem definition, causal interpretation, moral evaluation, and/or treatment recommendation for the item described" [30]. This study analyses the framing of the impact of robots on the employment situation of disabled people evident in Canadian newspapers and international academic articles. Newspapers are chosen as a source of data because newspapers have a "vital role to play in generating keyword recognition" for the general public [31] and they can increase 
the interest in a topic [32]. Furthermore, newspapers are both a source and indicator of public opinion and have the power to inform or not inform the public about an event, and to construct reality from a particular perspective [33]. Academic literature, which is increasingly available in open access format is also influential in shaping knowledge available and how readers might perceive a topic.

The findings are discussed through the lens of two studies on robots and employment-one from the USA [17] and one from Europe [18] and the United Nations Convention on the Rights of Persons with Disabilities [34] which highlights various problems disabled people face, such as obtaining employment and having access to technology and assistive devices.

\subsection{Data Source and Sampling}

The Canadian Newsstand Complete ProQuest database, with a collection of 300 Canadian newspapers, was accessed through the University of Calgary to obtain data on the newspaper coverage of the impact of robots on the employment situation of disabled people. A search was conducted on 14 August 2015 for the terms: "robot" AND "employment" AND disab*; "robot" AND "job" AND disab* and "robot" AND "work" AND "disab*. The term "disab" was used to cover phrases such as "people with disabilities", "disabled people", "disabled" and "disability". The resulting $n=991$ articles were downloaded and uploaded into Atlas.ti7@, a qualitative data analysis and research software.

To obtain data from the academic literature four academic databases (EBSCO All—an umbrella database that consists of over 70 other databases, Scopus, Science Direct and Web of Science) were searched on 14 August 2015 for the terms: "robot" (keyword 1) AND "employment" OR "job" OR "work" (keyword 2) AND "disabled people", OR "people with disabilities", OR "disabled person", OR "person with a disability" in the article title, article abstract, or keyword (Scopus and Science Direct), article abstract ( EBSCO All) or "topic" (Web of Science). The abstracts of the resulting $n=236$ results were downloaded and uploaded into Atlas.ti7@, a qualitative data analysis and research software.

\subsection{Data Analysis}

In the first step of the analysis the hit counts obtained with the keyword strategies outlined in Section 2.1 were recorded (see Tables in Sections 3.1 and 3.2). In the second step of the analysis, a deductive and inductive coding strategies was performed to obtain qualitative data from the articles uploaded into Atlas.ti7(C. As for deductive strategies, the Auto-coding function of Atlas.ti7@ was used to code every document downloaded into Atlas.ti7@ for the terms "disab*", "job", "employ*" and "work". This allowed for the identification of relevant sections in the documents. These coded areas were then read inductively and iteratively and themes relevant to the research questions were identified as reading progressed.

\subsection{Limitation}

The in-depth content analysis of newspaper articles in this study is limited to Canadian English language only newspapers. As such, the findings are not generalizable for Canada as a whole due to missing French language newspapers or other countries and the data cannot be used to judge other forms of media. Furthermore this study investigated only academic articles listed within the four chosen databases: EBSCO All, Scopus, Science Direct, and Web of Science. Although the focus of the journals covered by the four databases is in-sync with the research questions of this study, the databases have a certain selection bias as to the types of journals represented; for example three of the four leading disability studies journals are not represented by the databases (these journals' were searched for content using their own webpages). Therefore the findings from this study cannot be generalized for all academic literature; however, the data and the journals covered in this study will provide the reader with some ideas as to the current situation and the findings can be used to guide future research in this area. 


\section{Results}

\subsection{Academic Coverage}

As a first step it was determined how often investigated terms appeared in the journals covered by the four academic databases (Table 1).

Table 1. Coverage of the topic of employment of disabled people and robots within the academic literature.

\begin{tabular}{|c|c|c|c|}
\hline $\begin{array}{c}\text { First } \\
\text { Keyword }\end{array}$ & $\begin{array}{l}\text { Second } \\
\text { Keyword }\end{array}$ & Third Keyword & $\begin{array}{l}\text { Results from Academic Databases: EBSCO All, } \\
\text { Scopus, Science Direct, and Web of Science }\end{array}$ \\
\hline \multirow{15}{*}{ robot } & \multirow{5}{*}{ work } & "disabled people" & 102 \\
\hline & & "people with disabilities" & 58 \\
\hline & & "disabled person" & 8 \\
\hline & & "person with a disability" & 2 \\
\hline & & Patient & 1862 \\
\hline & \multirow{5}{*}{ job } & "disabled people" & 6 \\
\hline & & "people with disabilities" & 2 \\
\hline & & "disabled person" & 0 \\
\hline & & "person with a disability" & 0 \\
\hline & & Patient & 53 \\
\hline & \multirow{5}{*}{ employment } & "disabled people" & 0 \\
\hline & & "people with disabilities" & 0 \\
\hline & & "disabled person" & 0 \\
\hline & & "person with a disability" & 0 \\
\hline & & Patient & 34 \\
\hline
\end{tabular}

\subsubsection{Descriptive Quantitative Coverage}

Table 1 shows that very few hit counts were found (especially given the fact that the term "robot" generates 541,308 hits by itself and 71,911 hits in conjunction with the terms "work" or "employment" or "job) and that hits obtained were mostly linked to the presence of the term "work" and the term "patient". The terms "people with disabilities" or "disabled people" generated much less hits and terms, such as "disabled person" or "person with a disability", resulted in zero or very few hits.

\subsubsection{Descriptive Qualitative Data}

In the second step it was ascertained what was exactly said in regards to robots and the employment situation of disabled people in the $n=236$ abstracts of the academic articles downloaded. It was found that many of the abstracts revealed that the article did not engage with the topic of disabled people and their work/employment/job situation in any way. Indeed the term "work" was often a false positive used to highlight the "work" of the researcher. Of the abstracts with relevant content the term robot was used to cover robotic arms, brain-computer interfaces, exoskeletons, and wheelchairs as hardware. As to content linked to the employment situation of disabled people two articles covered FRIEND_-"a robot that was developed to supports a quadriplegic individual to work as a librarian with the task of retrospectively cataloging collections of old books. All of the book manipulation tasks, such as grasping the book from the book cart and placing it on the specially designed book holder for reading by the end user, are carried out autonomously by the FRIEND system" [35] (see also [36]). The AFMASTER workstation is another product mentioned [37] and a third product mentioned is an assistive mobile robot (mimicking a forklift) that help disabled people to work in a factory environment [38]. One article was a scoping review on the impacts of the use of a robotic arm by people living with upper limb motor impairment obtaining an overview of what 
has been reported until now in the scientific literature [39]. One study examined a human-robot collaboration system to support the aged or disabled person to work again and live a comfortable life [40]. The development of a mobile personal robot was reported as an attractive solution, even in economic terms, in comparison with desktop workstations [41,42]. Intelligent mapping from a haptic user interface to a remote manipulator was seen to be useful to assist individuals with disabilities performing occupational therapy tasks [43]. One article just mentioned that these devices might be useful for work [44]. Many articles were focusing on enabling daily rather than work related tasks of disabled people (for example [45-54]) or products that help disabled people (for example [55]). One exploratory study covered "the use of standard occupational therapy assessment tests to measure the effective manipulation ability of individuals with disabilities using a robotic aid" [56]. One article proposed the use of the international classification of functioning, disability and health (ICF) to answer questions such as: "what kind of function the robot can provide?", "who can use/who should not use the robot?", "when and where can the robot work?" [57].

Only two articles looked at social aspects: One article evaluated human-friendly human-machine interactions employing the task-oriented design (TOD) principle in three setting: a smart house system for the elderly/the disabled; a factory environment for the elderly/the disabled, and a hospital surgery room for medical doctors [58]. The second article titled, "Socially Responsible Engineering Education Through Assistive Robotics Projects: The RoboWaiter Competition" [59] proposed an approach to promote students' social awareness as part of challenging projects in robot design. The article highlighted RoboWaiter, the first international robot competition in the area of assistive robotics and described the dialogue among the Robot designers and members of the Connecticut Council on Developmental Disabilities (CTCDD) around the development of RoboWaiter. The authors concluded that these interactions made students realize "the social challenge of assistive robotics and to understand that engineering work has importance beyond pure technical achievement" [59].

Not one article thematized a negative impact of robots on the employment situation of disabled people and disabled people as co-workers of robots.

\subsection{Newspaper Coverage}

\subsubsection{Descriptive Quantitative Coverage}

In the third step, it was determined in how many articles the investigated terms appeared in the Canadian newspapers, at what time, in which newspaper and what type of article.

Table 2 shows that if the term "robot" was mentioned together with "disab" in an article, the terms "work" or "employment" or "job" were also often present. However, disab* was only mentioned in $1.5 \%$ of the articles that mentioned robots. Given that the article counts reflect $n=300$ newspapers and a timeframe from 1970-2015 the article count results for the terms searched is rather low. Dissecting the numbers further the following was found: as to the 329 articles covering Robot (+employment OR + job) + disab* only $n=9$ Canadian newspapers covered this topic in more than one article: The Globe and Mail $n=32$; The Ottawa Citizen, $n=26$; Toronto Star, $n=25$; Edmonton Journal, $n=23$; The Gazette, $n=23$; National Post, $n=23$; Calgary Herald, $n=17$; The Vancouver Sun, $n=15$; The Windsor Star, $n=14$.

The types of articles that covered the topic were as follows: News, $n=282$; Article, $n=51$; Feature, $n=48$; and Review, $n=31$. There were no articles written as letters to the editor. 
Table 2. Coverage of the topic of employment of disabled people and robots within Canadian newspapers.

\begin{tabular}{|c|c|c|c|c|c|c|c|c|}
\hline \multirow{2}{*}{$\begin{array}{c}\text { Key } \\
\text { Term } 1\end{array}$} & \multirow{2}{*}{ Key Term 2} & \multirow{2}{*}{$\begin{array}{c}\text { Key } \\
\text { Term } 3\end{array}$} & \multicolumn{6}{|c|}{ Canadian Newsstand Complete } \\
\hline & & & Total & 1970-1979 & 1980-1989 & 1990-1999 & 2000-2009 & 2010-2015 \\
\hline Robot & - & - & 61,500 & 148 & 4302 & 11,127 & 31,050 & 14,872 \\
\hline Robot & - & Disab $^{*}$ & 1233 & 2 & 89 & 244 & 614 & 287 \\
\hline Robot & employment OR job & - & 11,692 & 19 & 1088 & 2439 & 5229 & 2917 \\
\hline Robot & employment OR job & Disab* & 329 & 0 & 27 & 80 & 169 & 55 \\
\hline Robot & Work & - & 25,401 & 81 & 1823 & 4786 & 12,360 & 6351 \\
\hline Robot & Work & Disab* & 668 & 1 & 54 & 128 & 327 & 169 \\
\hline
\end{tabular}

Of the 668 articles covering Robot + work + disab* only $n=15$ newspapers covered this topic in more than one article: The Ottawa Citizen, $n=63$; The Globe and Mail, $n=59$; Edmonton Journal, $n=53$; Toronto Star, $n=50$; Calgary Herald, $n=45$; The Gazette, $n=43$; National Post, $n=39$; The Vancouver Sun, $n=39$; The Province, $n=23$; The Windsor Star, $n=22$; Kingston Whig-Standard, $n=19$; The Spectator, $n=19$; Times-Colonist, $n=19$; The Record, $n=16$; and Winnipeg Free Press, $n=13$. The types of articles that covered these topics were as follows: News, $n=598$; Article, $n=93$; Feature, $n=87$; Review, $n=28$; General Information, $n=14$. There were no articles written as letters to the editor.

The results suggest that readers of Canadian newspapers in many places of the country might never have been exposed to an article on the topic of robots and their linkage to the employment situation of disabled people.

\subsubsection{Descriptive Qualitative Coverage}

In the fourth step, the $668+329$ newspaper articles obtained around robots + (job or work or employment) + disab* were read to obtain an idea of what was said on the topic investigated. Only $n=9$ articles mentioned the use of robots in relation to the employment of disabled people. One article featured the developer of a voice activated robot arm highlighting its use for "turning pages in books, dialing telephones, preparing a drink and picking up objects of up to two kilograms" [60]; the use of a robotic arm for a work station was also mentioned in Reference [61]. Another article stated that the "robotic arm, originally designed to assemble General Motors vehicle dashboards, should encourage hiring of the disabled in the pizza industry" $[62,63]$. One article suggested one reason for encouraging the use of robots for disabled people in employment stating: "Saddled with enormous medical and health care costs for the severely handicapped, the companies in the U.S. apparently believe that if robots could help a handicapped person earn a living again, costs would be cut dramatically" [64] and "Weisel said there are approximately 50 million people perfected to assist the severely disabled. The service robots represent a major step forward in technology and for the first time will permit quadriplegics to become functional and productive in home and work environments" [64]. A third article gave voice to the opinion of University researchers and robotic industry officials that believe "robotic technology could provide unprecedented independence for the severely disabled, allowing them to handle office jobs in the booming service sector" [65]. The same article stated further: "With a system like this available to the disabled, it is going to allow them to be contributing members of society. Not to take from society, but to give, and that's all people in a wheelchair want to do" [65]. A robotic work station that would allow disabled people to work in an office was covered in [66]. One article covered a device that allowed "quadriplegics and others who have lost the use of their upper bodies to run any IBM-compatible computer program, and operate a telephone" [67]. The same article indicated that "American insurance companies are enthusiastic about the machine, which could let them cut the number of people on disability insurance because they can't get jobs" [67]. One article covered the Pizzabot-a robot developed at sthe Centre for Human Service Robotics at the Carnegie Mellon Research Institute "to help the disabled and elderly secure meaningful jobs, and to give them the opportunity to become small-business entrepreneurs" [68]. One article mentioned driverless cars and their availability by 2018 which are seen to "take blind or disabled people anywhere" [69]. 


\section{Discussion}

The findings of this study suggest a neglect of engagement with the impact of robots on the employability and employment situation of disabled people in Canadian newspapers and the academic literature covered. If robots were mentioned they were mentioned within the narrative of technology helping disabled people to obtain employment and technology helping so called abled bodied workers in their work with disabled people as their clients or patients. No article thematized that robots might decrease the employment rate for disabled people by competing with disabled people for the job, for example, and no article thematized disabled people being co-workers of robots.

\subsection{The Issue of Coverage in Canadian Newspapers}

That only $n=9$ newspaper articles cover the area of robots improving the employment situation of disabled people and $n=0$ newspaper articles thematized the area of robots decreasing the employment situation of disabled people is highly problematic especially given how broad the newspapers interpret robots. For example, one article highlighted driverless cars being available by 2018 which can function to "take blind or disabled people anywhere" [69]. The reader of the Canadian newspapers covered will never be triggered to think about the negative consequences of robots on the employment situation of disabled people which is a problem.

The study on robots and employment from the USA found the following reasons to be hopeful: (1) Advances in technology may displace certain types of work, but historically they have been a net creator of jobs; (2) We will adapt to these changes by inventing entirely new types of work, and by taking advantage of uniquely human capabilities; (3) Technology will free us from day-to-day drudgery, and allow us to define our relationship with "work" in a more positive and socially beneficial way; (4) Ultimately, we as a society control our own destiny through the choices we make [17].

As to point 1 of the study from the USA, looking at the employment situation of disabled people in the USA, for example, technology advancements acting as a net creator of jobs have so far not ensured that disabled people have access to these newly created jobs in sufficient numbers to improve the employment situation of disabled people. Given the jobs disabled people are mostly occupying today [25] (for data tables see [26-28]) it is doubtful that disabled people will be taking over as many or more of the new jobs envisioned to be created in relation to robots than they are losing the jobs that robots will take over. As to point 2, it is not clear what "unique human capabilities" means. If this is to mean that robots cannot take jobs that require social interactions this reason to be hopeful might not hold up if the field of social robotics advances as anticipated-where robots are able to interact socially with other robots and humans [70]. Furthermore disabled people have much lower abilities to adapt and it is questionable, given history, that disabled people generate a trend in taking on new jobs. Point three also seems to be based on the position of the privileged who have jobs, due to fulfilling bodily ability expectations, that make them highly adaptable. How will this point work for the $80 \%$ of disabled people who are not employed and the $28.7 \%$ of US civilians with disabilities of working-age in 2013 that live in poverty [21]? Finally, it is more than doubtful that disabled people control their destiny and the choices made by society which are detrimental to them. Rather, the reason the social situation of disabled people is so bad is because they do not control the destiny. The hopeful themes of the US study [17] were very likely developed by people who are privileged in that they feel they can adapt and control events to a certain extent; however, it is doubtful that disabled people would express this sentiment as a group.

The US study also lists reasons to be concerned: (1) Impacts from automation have thus far impacted mostly blue-collar employment; the coming wave of innovation threatens to upend white-collar work as well; (2) Certain highly-skilled workers will succeed wildly in this new environment-but far more may be displaced into lower paying service industry jobs at best, or permanent unemployment at worst; (3) Our educational system is not adequately preparing us for work of the future, and our political and economic institutions are poorly equipped to handle these 
hard choices [17]. The reasons to be concerned voiced in the US study all impact disabled people to a greater extent than so called non-disabled people.

The lack of newspaper coverage of the impact of robots on the employment situation of disabled people disempowers the reader. According to the EU study, 51\% disagree that "widespread use of robots can boost job opportunities in the EU" [18]; however, by omission, it leaves readers to think everything is fine for disabled people which disempowers the reader as it does not give the reader the information needed to decide whether action on the reader's part is warranted. The lack of coverage also disempowers disabled people because if they mention problems they have related to robots people will react surprised.

Although the non-existent coverage of robots in the context of robots endangering the employment of disabled people is problematic, it is not surprising. Newspapers are known to be influenced by their environment including ownership, funding, need for circulation, advertisement revenue and the readers' preference for reading like-minded news [71-94]. The bias of how newspapers report on disabled people is well known in the areas of how disabled people are portrayed [95-111], how the coverage of topics of importance to disabled people ignore disabled people [112] and how many topics that report on disabled people do so in a problematic way $[33,113,114]$.

However, it is more surprising that not more stories cover robots helping disabled people to gain employment. These make special interest stories, are cutting edge and readers like to read about positive applications of science and technology. Given how broad the newspapers interpret the term robot many opportunities have existed over time to report on the topic. For example, in the last few years, social robots (robots that are able to engage in social interaction with other robots and humans) have been envisioned to be of use for disabled people [70,115-124]; however, there was no article in the newspapers that covered the role or application of social robots for disabled people.

As to what to do, one path of action as a scholar is to record this lack of coverage to provide evidence, something that is seen often to be missing $[125,126]$. The study presented here fits with Haller et al.'s suggestion for disability studies scholars to continue to provide evidence on how disabled people are covered globally in the media [127]. As for disabled people, as long as they are seen as the 'other' and as long as the readers do not identify with the social reality of disabled people and as such want to read about disabled people within a social justice angle the coverage of disabled people might not change. Of course, for many topics, one can obtain information from other sources such as social media and Internet user groups covering a specific topic. However given that the topic of robots impacting the employment of disabled people is so far an anticipated problem with not many robots being used that displace already disabled people not many disabled and so called non-disabled people are involved in the governance of robots as it pertains to the employability of disabled people. There are no Facebook groups that cover robots and employment of disabled people. Another path open is for people to read employment related publications such as the one from the International Labor Organization and for people to raise the issue of robots impacting the employability of disabled people in such employment related publication; however, such publications will only reach and be read by certain groups and will not likely reach the general public as newspapers do.

As much as the lack of newspaper coverage is problematic, what is even more problematic is the lack of academic engagement with the topic.

\subsection{The Issue of Coverage in the Academic Literature}

Although it may be understandable why the potentially negative impact of robots on the employment of disabled people has not been covered in Canadian newspapers it is less understandable why no studies exist on the impact of robots on the employability of disabled people especially given the fact that the impact of robots on employment in general is discussed extensively in the academic literature (for example, see [1-14,17,18]).

Various academic fields of which articles show up in the academic database covered could have looked into the impact of robots on the employment situation of disabled people. The goal of 
science, technology and innovation governance is to decrease negative and increase positive impacts of science, technology and innovation. Anticipatory governance and responsible innovation are two prominent science, technology and innovation governance frameworks. Anticipatory governance draws on foresight and stakeholder engagement to enrich science, technology and innovation governance [128-131] while responsible innovation focuses on ethical acceptability, sustainability and societal desirability of innovations [132].

Another field that comes to mind is the field of occupational therapy, which has the goal to promote health and well-being by enabling people to obtain, maintain and enjoy occupations [133]. Another field is occupational science, which is seen as an emerging basic science, which supports the practice of occupational therapy field of occupational science [134-136].

Disability Studies is another academic field which could have covered the topic. Of the four established academic journals (Disability and Society a journal covered by our database search and Disability Studies Quarterly; Canadian Journal of Disability Studies and Review in Disability Studies three journals not covered by our database searches and as such looked at manually) none have so far covered this topic (data not shown).

Social work is another discipline which could have looked at the topic given that according to the 10th Edition of the National Association of Social Workers (USA) (NASW) Policy Statements, social work is engaged in areas such as social justice, education, poverty, genetics, diversity, well-being, human rights, workplace discrimination, community development, economic justice and is covering disabled people [137]. However, robots are not dealt with in relation to disabled people [138].

The list of potential disciplines that could have taken up the topic is much longer. All of the mentioned disciplines and many other disciplines could interrogate the implications of the study from the USA [17] and the study from Europe [18] as they pertain to disabled people and employment. All of the academic fields mentioned could use robots as a case study to investigate the usefulness of technologies for the employment situation of disabled people. Technologies are developed constantly yet $50 \%-80 \%$ of disabled people still are not working [19-22] with little movement in many years. Does that mean that technology is not as helpful as it is stated? Or is it the issue of access to the employment enabling technology?

To engage with the topic is also warranted given the United Nations Convention on the Rights of Persons with Disabilities [34]. In Article 27-Work and Employment of the United Nations Convention on the Rights of Persons with Disabilities it is stated that "States Parties recognize the right of persons with disabilities to work, on an equal basis with others; this includes the right to the opportunity to gain a living by work freely chosen or accepted in a labour market and work environment that is open, inclusive and accessible to persons with disabilities" [34]. Robots impact disabled people in different ways than so called non-disabled people and impacts disabled people with different abilities in different ways. As such the premise of "equal basis with others" in Article 27 suggests that knowledge and evidence pertaining to this aspect of robots and disabled people warrants investigation. The United Nations Convention on the Rights of Persons with Disabilities [34] mentions, in various areas, the issue of assistive devices and technologies and the issue of access to them. Given where the development of robots is moving the question arises whether robots are an assistive device as understood by United Nations Convention on the Rights of Persons with Disabilities. It also raises the question whether access to the robot which fits with the demand of the United Nations Convention on the Rights of Persons with Disabilities to increase the access of disabled people to technologies [34] would solve the problem robots pose or whether the access demand would even apply. One could make a case that many robots might not classify as an assistive device for disabled people and as such robots might become a problem under the premise of the United Nations Convention on the Rights of Persons with Disabilities because having access to the robot would not fit with the robot itself being the object filling the job position and disabled people competing with the robot for a given job. Anticipated developments of robots including social robots suggest a language and scope shortage of 
how the United Nations Convention on the Rights of Persons with Disabilities engaged with the topic of assistive devices and technology.

The findings from this study hopefully triggers interest among various academic fields including the ones that are engaged in the development of robots to engage with the potential positive and negative impacts of robots on the employment situation of disabled people.

\section{Conclusions and Further Research}

The findings suggest a neglect of engagement with the potential issues disabled people will face in relation to robots and employment in Canadian newspapers and the academic literature covered. If robots were mentioned they were mentioned within the narrative of technology helping disabled people to obtain employment and technology helping so called abled bodied workers in their work with disabled people as their clients or patients. No article thematized that robots might decrease the employment rate of disabled people for example by competing with disabled people for the same job and no article thematized disabled people being co-workers of robots.

The findings of the study is highly problematic; however not surprising. The two surveys mentioned in the introduction $[17,18]$ both highlight numerous issues that will impact disabled people differently or to a greater extent. However the surveys do not indicate that disabled people were targeted or specifically coded for in these studies. To the best of the author's knowledge, no study or survey exists that looked specifically at what disabled people with different backgrounds (ability, employment, income, etc.) think about robots. Given the findings of this study of a lack of academic engagement with the impact of robots on the employment situation of disabled people this might be a useful research study to pursue. It is well recognized that data is lacking with regards to many issues that disabled people face [125]. At the same time, it is recognized that one should govern science, technology and innovation in an anticipatory way [128,130,131]. Robotics and its impact on employment and employability of disabled people might be a fruitful area for generating evidence in an anticipatory way. Such an engagement would also fit with various articles under the United Nations Convention on the Rights of Persons with Disabilities [34].

Acknowledgments: I would like to thank the reviewers for their service and my students for being an inspiration.

Conflicts of Interest: The author declares no conflict of interest.

\section{References}

1. Howell, D.R. The future employment impacts of industrial robots: An input-output approach. Technol. Forecast. Soc. Chang. 1985, 28, 297-310. [CrossRef]

2. Weiss, A.; Igelsbock, J.; Wurhofer, D.; Tscheligi, M. Looking forward to a robotic society? Notions of future human-robot relationships. Int. J. Soc. Robot. 2011, 3, 111-123. [CrossRef]

3. Qureshi, M.O.; Syed, R.S. The impact of robotics on employment and motivation of employees in the service sector, with special reference to health care. Saf. Health Work 2014, 5, 198-202. [CrossRef] [PubMed]

4. Campa, R. Workers and automata: A sociological analysis of the italian case. J. Evol. Technol. 2014, 24, 70-85.

5. Peláez, A.L. The Robotics Divide; Springer: Berlin/Heidelberg, Germany, 2014.

6. Kaplan, J. Humans Need not Apply: A Guide to Wealth and Work in the Age of Artificial Intelligence; Yale University Press: New Haven, CT, USA, 2015.

7. Ford, M. Rise of the Robots: Technology and the Threat of a Jobless Future; Basic Books: New York, NY, USA, 2015.

8. Royakkers, L.; van Est, R. A literature review on new robotics: Automation from love to war. Int. J. Soc. Robot. 2015, 7, 549-570. [CrossRef]

9. Ebel, K.-H. The impact of industrial robots on the world of work. Int. Lab. Rev. 1986, 125, 39-51. [CrossRef]

10. Levitan, S.A.; Johnson, C.M. The future of work: Does it belong to us or to the robots. Mon. Lab. Rev. 1982, $105,10-14$.

11. Leontief, W.; Duchin, F. The Impacts of Automation on Employment, 1963-2000. Final report. Available online: http:/ /eric.ed.gov/?id=ED241743 (accessed on 26 April 2016). 
12. Kopacek, P.; Hersh, M. Roboethics. In Ethical Engineering for International Development and Environmental Sustainability; Springer: Berlin/Heidelberg, Germany, 2015; pp. 65-102.

13. Cyert, R.M., Mowery, D.C., Eds.; The Impact of Technological Change on Employment and Economic Growth; Ballinger Publishing Company: Pensacola, FL, USA, 1988.

14. Coyle, D. Welcoming our robot overlords: The disruptive potential of technological progress. In Technology, Globalisation and the Future of Work in Europe; Institute for Public Policy Research: London, UK, 2015; p. 100.

15. McNeal, M. Rise of the Machines: The Future Has Lots of Robots, Few Jobs for Humans. Available online: http:/ / www.wired.com/brandlab/2015/04/rise-machines-future-lots-robots-jobs-humans / (accessed on 26 April 2016).

16. West, D. What Happens if Robots Take the Jobs? The Impact of Emerging Technologies on Employment and Public Policy. Available online: http://www.brookings.edu/research/papers/2015/10/26-robotsemerging-technologies-public-policy-west (accessed on 26 April 2016).

17. Smith, A.; Anderson, J. AI, Robotics, and the Future of Jobs. Available online: http://www.pewinternet.org/ 2014/08/06/future-of-jobs/ (accessed on 26 April 2016).

18. European Commission. Public Attitudes towards Robots. Available online: http://ec.europa.eu/ public_opinion/archives/ebs/ebs_382_en.pdf (accessed on 25 April 2016).

19. 2014 Annual Disability Statistics Compendium. Available online: http://www.disabilitycompendium.org/ docs/default-source/2014-compendium/2014_compendium.pdf (accessed on 25 April 2016).

20. Persons with a Disability: Labor Force Characteristics Summary. Available online: http://www.bls.gov/ news.release/disabl.nr0.htm (accessed on 25 April 2016).

21. 2014 Disability Statistics Annual Report. Available online: http://www.disabilitycompendium.org/docs / default-source/2014-compendium/annual-report.pdf (accessed on 25 April 2016).

22. Employment of persons with disabilities. Available online: http://www.un.org/disabilities/documents / toolaction/employmentfs.pdf (accessed on 25 April 2016).

23. Evans Pete. Less than Half of Canadian Adults with Disabilities Have Jobs: Statscan. Available online: http:/ / www.cbc.ca/news/business/less-than-half-of-canadian-adults-with-disabilities-have-jobs-statscan1.2858954 (accessed on 25 April 2016).

24. Study: Persons with Disabilities and Employment. Available online: http://www.statcan.gc.ca/ daily-quotidien/141203/dq141203a-eng.htm (accessed on 25 April 2016).

25. Workers with a Disability Less Likely to be Employed, More Likely to Hold Jobs with Lower Earnings, Census Bureau Reports. Available online: https:/ /www.census.gov/newsroom/press-releases/2013/cb13-47.html (accessed on 25 April 2016).

26. Disability Employment 3. EEO-1 Job Categories by Disability Status, Sex, and Race/Ethnicity, Total Population, Number Universe: Civilian Labor Force 16 Years and Over. Available online: http:/ / factfinder.census.gov/faces/tableservices/jsf/pages/productview.xhtml?pid=EEO_10_3YR_DO LCIT3N\&prodType=table (accessed on 25 April 2016).

27. Disability Employment 2. EEO Occupational Groups by Disability Status, Sex, and Race/Ethnicity, Total Population, Number Universe: Civilian Labor Force 16 Years and Over. Available online: http:/ / factfinder.census.gov/faces/tableservices/jsf/pages/productview.xhtml?pid=EEO_10_3YR_DO LALL2N\&prodType=table (accessed on 25 April 2016).

28. Disability Employment 4. Federal Sector Job Groups by Disability Status, Sex, and Race/Ethnicity, Total Population, Number Universe: Civilian Labor Force 16 Years and over for whom Census Occupation has a Federal Government Counterpart. Available online: http:/ factfinder.census.gov/faces/tableservices / jsf/pages/productview.xhtml?pid=EEO_10_3YR_DOLALL4N\&prodType=table (accessed on 25 April 2016).

29. Vliegenthart, R.; van Zoonen, L. Power to the frame: Bringing sociology back to frame analysis. Eur. J. Commun. 2011, 26, 101-115. [CrossRef]

30. Entman, R.M. Framing: Towards clarification of a fractured paradigm. J. Commun. 1993, 43, 51-58. [CrossRef]

31. Wolbring, G.; Leopatra, V.; Yumakulov, S. Information flow and health policy literacy: The role of the media. Information 2012, 3, 391-402. [CrossRef]

32. Levy, B.L.; Zint, M.T. Toward fostering environmental political participation: Framing an agenda for environmental education research. Environ. Educ. Res. 2013, 19, 553-576. [CrossRef]

33. Tynedal, J.; Wolbring, G. Paralympics and its athletes through the lens of the new york times. Sports 2013, 1, 13-36. [CrossRef] 
34. United Nations. Convention on the Rights of Persons with Disabilities. Available online: http://www.un. org/disabilities/documents/convention/convoptprot-e.pdf (accessed on 25 April 2016).

35. Graser, A.; Heyer, T.; Fotoohi, L.; Lange, U.; Kampe, H.; Enjarini, B.; Heyer, S.; Fragkopoulos, C.; Ristic-Durrant, D. A supportive friend at work: Robotic workplace assistance for the disabled. IEEE Robot. Autom. Mag. 2013, 20, 148-159. [CrossRef]

36. Ivlev, O.; Martens, C.; Graeser, A. Rehabilitation robots FRIEND-I and FRIEND-II with the dexterous lightweight manipulator. Technol. Disabil. 2005, 17, 111-123.

37. Gelin, R.; Lesigne, B.; Busnel, M.; Michel, J.-P. The first moves of the afmaster workstation. Adv. Robot. 2001, 14, 639-649. [CrossRef]

38. Kang, J.W.; Kim, B.S.; Chung, M.J. Development of assistive mobile robots helping the disabled work in a factory environment. In Proceedings of the IEEE/ASME International Conference on Mechtronic and Embedded Systems and Applications, Beijing, China, 12-15 October 2008; pp. 426-431.

39. Beaudoin, M.; Routhier, F.; Lettre, J.; Archambault, P.; Lemay, M. Effects and impacts of a robotic arm used by individuals with upper limb motor impairment: A scoping review. Ann. Phys. Rehabil. Med. 2015, 58, e98. [CrossRef]

40. Noritsugu, T.; Tsuji, Y. A task assist system using a rubber artificial muscle manipulator. Adv. Robot. 2000, 14, 363-365. [CrossRef]

41. Hoppenot, P.; Colle, E. Human-like behavior robot-application to disabled people assistance. In Proceedings of the 2000 IEEE International Conference on Systems, Man, and Cybernetics, Nashville, TN, USA, 8-11 October 2000; pp. 155-160.

42. Hentout, A.; Benbouali, M.; Akli, I.; Bouzouia, B.; Melkou, L. A telerobotic human/robot interface for mobile manipulators: A study of human operator performance. In Proceedings of the 2013 International Conference on Control, Decision and Information Technologies (CoDIT), Hammamet, Tunisia, 6-8 May 2013; pp. 641-646.

43. Pernalete, N.; Yu, W.; Dubey, R.; Moreno, W. Telerobotic haptic system to assist the performance of occupational therapy tests by motion-impaired users. In Proceedings of the IEEE International Conference on Robotics and Automation, Taipei, Taiwan, 14-19 September 2003; pp. 1247-1252.

44. Bühler, C.; Hoelper, R.; Hoyer, H.; Humann, W. Autonomous robot technology for advanced wheelchair and robotic aids for people with disabilities. Robot. Auton. Syst. 1995, 14, 213-222. [CrossRef]

45. Peña González, A.; Gil-Agudo, A.; Jardón, A. Functional evaluation of asibot, a portable robot to aid disabled persons. In Proceedings of the International Congress on Domotics, Robotics and Remote-Assistance for All, Madrid, Spain, 13-15 June 2007; pp. 79-86.

46. Dietsch, J.; Jardon, A.; Gimenez, A.; Correal, R.; Cabas, R.; Martinez, S.; Balaguer, C. A portable light-weight climbing robot for personal assistance applications. Ind. Robot Int. J. 2006, 33, 303-307. [CrossRef]

47. Tsuji, T.; Mozos, O.M.; Chae, H.; Pyo, Y.; Kusaka, K.; Hasegawa, T.; Morooka, K.; Kurazume, R. An informationally structured room for robotic assistance. Sensors 2015, 15, 9438-9465. [CrossRef] [PubMed]

48. Valente, P.; Hossain, S.; Gronbak, B.; Hallenborg, K.; Reis, L.P. A multi-agent framework for coordination of intelligent assistive technologies. In Proceedings of the 5th Iberian Conference on Information Systems and Technologies (CISTI), Santiago de Compostela, Spain, 16-19 June 2010; pp. 1-6.

49. Kohtsuka, T.; Onozato, T.; Tamura, H.; Katayama, S.; Kambayashi, Y. Design of a control system for robot shopping carts. In Knowledge-Based and Intelligent Information and Engineering Systems; Springer: Berlin/Heidelberg, Germany, 2011; pp. 280-288.

50. Dario, P.; Guglielmelli, E.; Laschi, C.; Teti, G. Movaid: A personal robot in everyday life of disabled and elderly people. Technol. Disabil. 1999, 10, 77-93.

51. Guilherme, N.; DeSouza, D.; Tsui, M.K.; McCann, E.; McHugh, A.; Medvedev, M.; Yanco, A.H.; Kontak, D.; Drury, L.J. Towards designing telepresence robot navigation for people with disabilities. Int. J. Intell. Comput. Cybern. 2014, 7, 307-344. [CrossRef]

52. Cunningham, A.; Keddy-Hector, W.; Sinha, U.; Whalen, D.; Kruse, D.; Braasch, J.; Wen, J.T. Jamster: A mobile dual-arm assistive robot with jamboxx control. In Proceedings of the 2014 IEEE International Conference on Automation Science and Engineering (CASE), Taipei, Taiwan, 18-22 August 2014; pp. 509-514.

53. Turcu, C.; Turcu, C.; Gaitan, V. Integrating robots into the internet of things. Int. J. Circuits Syst. Signal Process. 2012, 6, 430-437. 
54. Grindle, G.G.; Wang, H.; Salatin, B.A.; Vazquez, J.J.; Cooper, R.A. Design and development of the personal mobility and manipulation appliance. Assist. Technol. 2011, 23, 81-92. [CrossRef]

55. Koyama, T.; Tanaka, T.; Tanaka, K.; Feng, M.Q. Interaction among human, machine and patient with work state transition. In Proceedings of the IEEE International Conference on Robotics and Automation, Taipei, Taiwan, 14-19 September 2003; pp. 2362-2367.

56. Schuyler, J.L.; Mahoney, R.M. Assessing human-robotic performance for vocational placement. IEEE Trans. Rehabil. Eng. 2000, 8, 394-404. [CrossRef] [PubMed]

57. Wakita, Y.; Tanaka, H.; Matsumoto, Y. Analysis and design of service robots based on ICF. In Proceedings of the 2014 IEEE International Conference on Robotics and Biomimetics (ROBIO), Bali, Indonesia, 5-10 December 2014.

58. Bien, Z.Z.; Chang, P.-H.; Yoon, Y.-S.; Park, K.-H.; Park, S.H.; Park, S.; Do, J.-H.; Lee, H.-E. Realization and evaluation of assistive human-mechatronic systems with human-friendly robotic agents at HWRS-ERC. In Proceedings of the IEEE 10th International Conference on Rehabilitation Robotics, Noordwijk, The Netherlands, 13-15 June 2007; pp. 328-334.

59. Ahlgren, D.J.; Verner, I.M. Socially responsible engineering education through assistive robotics projects: The robowaiter competition. Int. J. Soc. Robot. 2013, 5, 127-138. [CrossRef]

60. British Firm Introduces Robot to Help Elderly, Disabled. The Ottawa Citizen, 10 October 1986, p. B9.

61. Carefully Rethinking Your Intellectual Property. Kelowna Capital News, 25 May 2005, p. 21.

62. Robotic Arm Helping Woman Play Useful Role in Society. The Ottawa Citizen, 30 July 1991, p. D7.

63. Computers Give Disabled Hope. Kitchener-Waterloo Record, 25 July 1991, p. F2.

64. By Bill Shields Star Business, E. Robots Enter the Service Scene. The Windsor Star, 18 June 1988, p. A13.

65. Personal Robots Bring New Hope for Severely Disabled. The Vancouver Sun, 20 June 1988, p. B4.

66. Clocking in with the Steel Collar Worker. The Vancouver Sun, 18 March 1989, p. H1.

67. Gorrie, P. New system helps take place of hands. Toronto Star, 5 October 1989, p. E3.

68. Worrall, W.; Armstrong, J. Big Herb-Tea Company Was Started When Friends Gathered Mountain Herbs. The Gazette, 9 January 1991, p. D4.

69. Francis, D. Silicon Valley Brings Robots to the Masses. National Post, 13 December 2014, p. FP2.

70. Wolbring, G.; Yumakulov, S. Social robots: Views of staff of a disability service organization. Int. J. Soc. Robot. 2014, 6, 457-468. [CrossRef]

71. Reese, S.D. Understanding the global journalist: A hierarchy-of-influences approach. J. Stud. 2001, 2, $173-187$. [CrossRef]

72. Price, C.J. Interfering owners or meddling advertisers: How network television news correspondents feel about ownership and advertiser influence on news stories. J. Media Econ. 2003, 16, 175-188. [CrossRef]

73. Winseck, D. Netscapes of power: Convergence, consolidation and power in the canadian mediascape. Media Cult. Soc. 2002, 24, 795-819. [CrossRef]

74. Gilens, M.; Hertzman, C. Corporate ownership and news bias: Newspaper coverage of the 1996 telecommunications act. J. Politics 2000, 62, 369-386. [CrossRef]

75. Anderson, A. Media, politics and climate change: Towards a new research agenda. Sociol. Compass 2009, 3, 166-182. [CrossRef]

76. Schudson, M. The news media as political institutions. Annu. Rev. Political Sci. 2002, 5, 249-269. [CrossRef]

77. Baer, W.S.; Geller, H.; Grundfest, J.A.; Possner, K.B. Concentration of Mass Media Ownership: Assessing The State of Current Knowledge; RAND Corporation: Santa Monica, CA, USA, 1974.

78. Allport, G.W.; Faden, J.M. The psychology of newspapers: Five tentative laws. Public Opin. Q. 1940, 4, 687-703. [CrossRef]

79. Tilley, E.; Hollings, J. Still stuck in "a love-hate relationship": Understanding journalists' enduring and impassioned duality towards public relations. In Proceedings of the ANZCA 2008 Conference on Power and Place, Wellington, New Zealand, 9-11 July 2008.

80. Shoemaker, P.J.; Vos, T.P.; Reese, S.D. Journalists as gatekeepers. In Handbook of Journalism Studies, International Communication Association Handbook Series; Wahl-Jorgensen, K., Hanitzsch, T., Eds.; Routlege: London, UK, 2009; pp. 73-87.

81. McCauley, M.; Blake, K.; Meissner, H.; Viswanath, K. The social group influences of us health journalists and their impact on the newsmaking process. Health Educ. Res. 2013, 28, 339-351. [CrossRef] [PubMed] 
82. Sill, K.L.; Metzgar, E.T.; Rouse, S.M. Media coverage of the us supreme court: How do journalists assess the importance of court decisions? Political Commun. 2013, 30, 58-80. [CrossRef]

83. Weaver, D.; Elliott, S.N. Who sets the agenda for the media? A study of local agenda-building. J. Mass Commun. Q. 1985, 62, 87-94. [CrossRef]

84. Carragee, K.M.; Roefs, W. The neglect of power in recent framing research. J. Commun. 2004, 54, $214-233$. [CrossRef]

85. Bulkow, K.; Urban, J.; Schweiger, W. The duality of agenda-setting: The role of information processing. Int. J. Public Opin. Res. 2013, 25, 43-63. [CrossRef]

86. Illia, L.; Lurati, F.; Casalaz, R. Situational theory of publics: Exploring a cultural ethnocentric bias. J. Public Relat. Res. 2013, 25, 93-122. [CrossRef]

87. Roberts, M.; McCombs, M. Agenda setting and political advertising: Origins of the news agenda. Political Commun. 1994, 11, 249-262. [CrossRef]

88. Abbring, J.H.; van Ours, J.C. Selling news and advertising space: The economics of dutch newspapers. Economist 1994, 142, 151-170. [CrossRef]

89. Reddaway, W.B. The economics of newspapers. Econ. J. 1963, 73, 201-218. [CrossRef]

90. George, L. What's fit to print: The effect of ownership concentration on product variety in daily newspaper markets. Inf. Econ. Policy 2007, 19, 285-303. [CrossRef]

91. White, J.M. Source Choice in Agricultural News Coverage: Impacts of Reporter Specialization and Newspaper Location, Ownership, and Circulation. Ph.D. Thesis, Texas A\&M University, College Station, TX, USA, 2013.

92. Gentzkow, M.; Shapiro, J.M. What drives media slant? Evidence from us daily newspapers. Econometrica 2010, 78, 35-71.

93. Stroud, N.J. Niche News: The Politics of News Choice; Oxford University Press: Oxford, UK, 2011.

94. Stroud, N.J.; Muddiman, A. Selective exposure, tolerance, and satirical news. Int. J. Public Opin. Res. 2013, 25, 279-290. [CrossRef]

95. Billawala, A.; Wolbring, G. Analyzing the discourse surrounding autism in the new york times using an ableism lens. Disabil. Stud. Q. 2014, 34. Available online: http://dsq-sds.org/article/view/3348/3524 (accessed on 25 April 2016). [CrossRef]

96. Huws, J.C.; Jones, R.S. Missing voices: Representations of autism in british newspapers, $1999-2008$. Br. J. Learn. Disabil. 2011, 39, 98-104. [CrossRef]

97. Jones, S.C.; Harwood, V. Representations of autism in australian print media. Disabil. Soc. 2009, $24,5-18$. [CrossRef]

98. Baker, D.L. Defining autism in canada: Unfolding the public aspects of neurological disability. Soc. Sci. J. 2007, 44, 687-697. [CrossRef]

99. Osteen, M. Autism and Representation; Routledge: New York, NY, USA, 2007.

100. Caruso, D. Autism in the us: Social movement and legal change. Am. J. Law Med. 2010, 36, 483-539. [PubMed]

101. Bertilsdotter Rosqvist, H.; Brownlow, C.; O'Dell, L. Mapping the social geographies of autism-online and off-line narratives of neuro-shared and separate spaces. Disabil. Soc. 2013, 28, 367-379. [CrossRef]

102. Boray, S. Depiction of disabilities in movies: Disability portrayal in the media through the eyes of bollywood and hollywood. Available online: http://papers.ssrn.com/sol3/papers.cfm?abstract_id=1943108 (accessed on 25 April 2016).

103. Conn, R.; Bhugra, D. The portrayal of autism in hollywood films. Int. J. Cult. Ment. Health 2012, 5, 54-62. [CrossRef]

104. Stevenson, J.L.; Harp, B.; Gernsbacher, M.A. Infantilizing autism. Disabil. Stud. Q. 2011, 31. Available online: http:/ /dsq-sds.org/article/view/1675/1596 (accessed on 25 April 2016). [CrossRef]

105. Waltz, M. Images and narratives of autism within charity discourses. Disabil. Soc. 2012, 27, $219-233$. [CrossRef]

106. Corrigan, P.W.; Watson, A.C.; Gracia, G.; Slopen, N.; Rasinski, K.; Hall, L.L. Newspaper stories as measures of structural stigma. Psychiatr. Serv. 2005, 56, 551-556. [CrossRef] [PubMed]

107. Kang, S. Coverage of autism spectrum disorder in the us television news: An analysis of framing. Disabil. Soc. 2013, 28, 245-259. [CrossRef] 
108. Young, L.S. Awareness with Accuracy: An Analysis of the Representation of Autism in Film and Television. Master's Thesis, College of Mass Communication and Media Arts, Carbondale, IL, USA, 2012.

109. Goggin, G.; Newell, C. Digital Disability: The Social Construction of Disability in New Media; Rowman \& Littlefield: Lanham, ML, USA, 2003.

110. Barnes, C. Disabling Imagery and the Media, an Exploration of the Principles for Media Representations of Disabled People; British Council of Organisations of Disabled People and Ryburn Publishing: Krumlin, UK, 1992.

111. Clogston, J.S. Disability coverage in american newspapers. In The Disabled, the Media and the Information Age; Nelson, J.L., Ed.; Greenwood Press: Westport, CT, USA, 1994; pp. 45-57.

112. Wolbring, G.; Mackay, R. Analysis of newspaper coverage of food security through a disability studies lens. J. Sustain. Dev. 2014, 7. [CrossRef]

113. Panesar, S.; Wolbring, G. Analysis of north american newspaper coverage of bionics using the disability studies framework. Technologies 2014, 2, 1-30. [CrossRef]

114. Wolbring, G.; Tynedal, J. Pistorius and the media: Missed story angles. Sports Technol. 2013, 6, 177-183.

115. Cabibihan, J.-J.; Javed, H.; Ang, M., Jr.; Aljunied, S.M. Why robots? A survey on the roles and benefits of social robots in the therapy of children with autism. Int. J. Soc. Robot. 2013, 5, 593-618. [CrossRef]

116. Wainer, J.; Dautenhahn, K.; Robins, B.; Amirabdollahian, F. A pilot study with a novel setup for collaborative play of the humanoid robot kaspar with children with autism. Int. J. Soc. Robot. 2014, 6, 45-65. [CrossRef]

117. Yumakulov, S.; Yergens, D.; Wolbring, G. Imagery of people with disabilities within social robotics research. Soc. Robot. 2012, 7621, 168-177.

118. Welch, K.C.; Lahiri, U.; Warren, Z.; Sarkar, N. An approach to the design of socially acceptable robots for children with autism spectrum disorders. Int. J. Soc. Robot. 2010, 2, 391-403. [CrossRef]

119. Boccanfuso, L.; O'Kane, J.M. Charlie: An adaptive robot design with hand and face tracking for use in autism therapy. Int. J. Soc. Robot. 2011, 3, 337-347. [CrossRef]

120. Thill, S.; Pop, C.A.; Belpaeme, T.; Ziemke, T.; Vanderborght, B. Robot-assisted therapy for autism spectrum disorders with (partially) autonomous control: Challenges and outlook. Paladyn 2012, 3, 209-217. [CrossRef]

121. Joosse, M.; Sardar, A.; Lohse, M.; Evers, V. BEHAVE-II: The revised set of measures to assess users' attitudinal and behavioral responses to a social robot. Int. J. Soc. Robot. 2013, 5, 379-388. [CrossRef]

122. Mejías, C.S.; Echevarría, C.; Nuñez, P.; Manso, L.; Bustos, P.; Leal, S.; Parra, C. Ursus: A robotic assistant for training of children with motor impairments. In Converging Clinical and Engineering Research on Neurorehabilitation; Springer: Berlin/Heidelberg, Germany, 2013; pp. 249-253.

123. Daly, I.; Billinger, M.; Laparra-Hernández, J.; Aloise, F.; García, M.L.; Faller, J.; Scherer, R.; Müller-Putz, G. On the control of brain-computer interfaces by users with cerebral paly. Clin. Neurophysiol. 2013, 124, 1787-1797. [CrossRef] [PubMed]

124. Wolbring, G.; Ghai, A. Interrogating the impact of scientific and technological development on disabled children in india and beyond. Disabil. Glob. South 2015, 2, 667-685.

125. World Report on Disability. Available online: http://www.who.int/disabilities/world_report/2011/en/ index.html (accessed on 26 April 2016).

126. The Swedish Disability Federation. Swedish Disability Movement's Alternative Report to the un Committee on the Rights of Persons with Disabilities. Available online: https://www.google.ca/url?sa=t\&rct=j\&q= \&esrc $=$ s\&source=web\&cd=1\&cad=rja\&uact=8\&ved=0CB4QFjAA\&url=http $\% 3 \mathrm{~A} \% 2 \mathrm{~F} \% 2 \mathrm{Fwww}$. ohchr.org

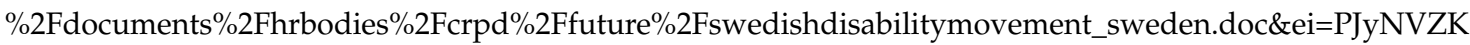
9NsTwoASj1rjwBA\&usg=AFQjCNEakVo8rBqva0n9paVq01DlVrxzfA\&sig2=EHqizYZUgrsky-5rcEWgLg (accessed on 26 April 2016).

127. Haller, B.; Rioux, M.; Dinca-Panaitescu, M.; Laing, A.; Vostermans, J.; Hearn, P. The place of news media analysis within canadian disability studies. Can. J. Disabil. Stud. 2012, 1, 43-74. [CrossRef]

128. Guston, D.H. Understanding 'anticipatory governance'. Soc. Stud. Sci. 2014, 44, 218-242. [CrossRef] [PubMed]

129. Barben, D.; Fisher, E.; Selin, C.; Guston, D. Anticipatory governance of nanotechnology: Foresight, engagement, and integration. In The Handbook of Science and Technology Studies, 3rd ed.; MIT Press: Cambridge, MA, USA, 2008; pp. 979-1000.

130. Diep, L.; Cabibihan, J.-J.; Wolbring, G. Social robotics through an anticipatory governance lens. In Social Robotics; Beetz, M., Johnston, B., Williams, M.-A., Eds.; Springer: Berlin/Heidelberg, Germany, 2014; Volume 8755, pp. 115-124. 
131. Guston, D. The anticipatory governance of emerging technologies. J. Korean Vac. Soc. 2010, 19, $432-441$. [CrossRef]

132. Von Schomberg, R. Prospects for technology assessment in a framework of responsible research and innovation. In Technikfolgen Abschätzen Lehren; Dusseldorp, M., Beecroft, R., Eds.; VS Verlag für Sozialwissenschaften: Wiesbaden, Germany, 2012; pp. 39-61.

133. Statement on Occupaitonal Therapy. Available online: http://www.wfot.org/Portals/0/PDF/STATEMENT \%20ON\%20OCCUPATIONAL\%20THERAPY\%20300811.pdf (accessed on 26 April 2016).

134. Yerxa, E.J. An introduction to occupational science, a foundation for occupational therapy in the 21st century. Occup. Ther. Health Care 1990, 6, 1-17. [CrossRef] [PubMed]

135. Clark, F.A.; Parham, D.; Carlson, M.E.; Frank, G.; Jackson, J.; Pierce, D.; Wolfe, R.J.; Zemke, R. Occupational science: Academic innovation in the service of occupational therapy's future. Am. J. Occup. Ther. 1991, 45, 300-310. [CrossRef] [PubMed]

136. Wilding, C.; Whiteford, G. From practice to praxis: Reconnecting moral vision with philosophical underpinnings. Br. J. Occup. Ther. 2009, 72, 434-441. [CrossRef]

137. Policy Statement Topic Areas: Social Work Speaks. Available online: http://www.naswpress.org/ publications/practice/inside/speaks-topic-areas.html (accessed on 26 April 2016).

138. Wolbring, G.; Diep, L. Engaging with technology governance in social work education: An essential for preparing future social work(ers). Int. J. Contin. Soc. Work Educ. 2014, 17, 63-75.

(C) 2016 by the author; licensee MDPI, Basel, Switzerland. This article is an open access article distributed under the terms and conditions of the Creative Commons Attribution (CC-BY) license (http://creativecommons.org/licenses/by/4.0/). 